\title{
Removal of Uranium from U-bearing Lime-Precipitate using dissolution and precipitation methods
}

\section{우라늄 함유 석회침전물의 용해 및 침전에 의한 U 제거}

\author{
Eil-Hee Lee' ${ }^{1)}$, Keun-Young Lee, Dong-Yong Chung, Kwang-Wook Kim, Kune-Woo Lee \\ and Jei-Kwon Moon \\ Korea Atomic Energy Research Institute, 989-111 Daedeok-Daero, Yuseong-Gu, Daejeon \\ 이일희1), 이근영, 정동용, 김광욱, 이근우, 문제권 \\ 한국원자력연구원, 대전시 유성구 대덕대로 989번길 111
}

(Received April 09, 2012 / Revised May 21, 2012 / Approved May 22, 2012)

\begin{abstract}
This study was carried out to remove (/recover) the uranium from the Uranium-bearing Lime Precipitate (ULP). An oxidative dissolution of ULP with carbonate-acidified precipitation and a dissolution of ULP with nitric acidhydrogen peroxide precipitation were discussed, respectively. In point of view the dissolution of uranium in ULP, nitric acid dissolution which could dissolved more than $98 \%$ of uranium was more effective than carbonate dissolution. However, in this case, uranium was dissolved together with a large amount of impurities such as $\mathrm{Al}$, Ca, $\mathrm{Fe}, \mathrm{Mg}, \mathrm{Si}$, etc. and some impurities were also co-precipitated with uranium during a hydrogen peroxide precipitation. On the other hand, in the case of carbonate dissolution-acidified precipitation, $U$ was dissolved less than $90 \%$. Therefore, it was less effective than nitric acid dissolution for the volume reduction of radioactive solid waste. However, it was very effective to recover the pure uranium, because impurities were hardly dissolved and hardly co-precipitated with uranium.
\end{abstract}

Key words : Uranium, Carbonate, Oxidative dissolution, Nitric acid dissolution, Acidified precipitation, Hydrogen peroxide precipitation

\section{요 약}

본 연구는 우라늄-함유 석회침전물로부터 U을 제거(/회수) 하기위하여 탄산염 산화용해-산성화 침전과 질산용해-과산화수소 침전을 각각 고찰하였다. 석회침전물 내 우라늄을 용해하는 관점에서는 질산용해가 유리하나 (약 $98 \%$ 이상 용해) 이 경우 $\mathrm{U}$ 과 $\mathrm{Al}, \mathrm{Ca}, \mathrm{Fe}, \mathrm{Mg}, \mathrm{Si}$ 등의 공존 불순물이 다량 공용해되고, 또한 과산화수소 침전에서도 상당량의 불순물이 U과 함께 공침전 된다. 한편 탄산염 용해에 의한 산성화 침전 은 우라늄의 용해가 $90 \%$ 이하로 방사성 고체페기물의 부피감용 측면에서는 질산용해 보다 덜 효율적이 지만, 우라늄과 불순물의 공용해나 산성화 침전에 의한 우라늄과 불순물의 공침전이 거의 일어나지 않아

1) Corresponding Author. E-mail : nehlee@kaeri.re.kr 
보다 순수한 $\mathrm{U}$ 을 회수하는 측면에서는 매우 효과적이다.

중심단어 : 우라늄, 탄산염, 산화용해, 질산용해, 산성화 침전, 과산화수소 침전

\section{I. 서 론}

우라늄 함유 물질 (uranium-bearing materials)은 원광 처 리, 정련, 변환 및 핵연료 가공 등과 같은 선행핵연료 주기나, 사용후핵연료 처리, 처분 등의 후행핵연료 주기에서 다양하 게 발생한다. 이들 대부분은 다른 금속물질 (산화물 등)이나 무기성 물질과 혼합된 우라늄 혼합물 (mixture) 형태로 존재 하고 있다. 그리고 우라늄 (Uranium: U) 자체가 방사성 물질 이기 때문에 자연환경에 직접 처분할 수 없어 대부분이 발생 장소에서 혼합물 형태로 저장하거나, 석회 (lime) 등으로 고 화처리 한 후 저장 관리하고 있다. 한국원자력연구원의 변환 시설에서 발생한 U-함유 혼합물도 석회로 처리한 후 이를 다 시 건조시켜 석회침전물 형태로 저장하고 있다. 석회침전물 의 저장 총량은 약 474 드럼 정도로 그리 많지 않으나 이의 방 사능이 약 4,000 4,500 Bq/g로 우리나라 경주 처분장 (저준 위 폐기물 처분장)의 처분 기준인 $3,700 \mathrm{~Bq} / \mathrm{g}$ [1] 보다 높고, 또한 경주 처분장의 처분 단가가 중저준위 방사성폐기물 처 분비용에 유치지역 지원금 등이 포함되어 처분용기 $200 \mathrm{~L}$ 드 럼 당 약 850 만원 이상이 고려되고 있다. [2] 그러므로 석회침 전물 (처분장에 처분할 시멘트 고화체로 제조하기 위하여 시 멘트와 석회침전물의 혼합 비율을 $1: 1$ 로 가정할 경우 총 처분 드럼 수는 약 960 드럼)을 모두 이 처분장에 처분할 경우 많은 예산이 소요될 것으로 보여 석회침전물로부터 $\mathrm{U}$ 을 제거//회 수) 처리하여 처분 용량의 저감화 및 비용 절감을 도모할 필 요가 있다.

다양한 용해성 및 불용해성 불순물과 U이 함께 함유된 석 회침전물로부터 $\mathrm{U}$ 의 회수/처리는 우선 석회침전물의 효율적 인 용해가 관건으로, 석회침전물에 함유된 U을 선택적으로 용해할 것이냐 또는 불순물과 U을 공용해할 것이냐에 따라 적용 용해 계 (system)가 다를 수 있으나, 근본적으로는 석회 침전물 자체를 모두 버리는 폐기물로 간주하였기 때문에 석 회침전물로부터 U의 용해 및 침전 회수/처리에 관한 연구는 지금까지 거의 수행되지 않은 실정이다. 다만 우라늄의 함량 이 높은 혼합물의 경우 전통적인 방법으로 고온/고산도 질산 에 의해 U과 불순물을 공용해한 후 용매추출하여 U을 제거// 회수)하고 있으나, [3-5] 장치의 부식문제, NOx 및 유기폐액 발생 등 다량의 2 차폐기물 발생으로 인하여 요즈음은 자연 친
화성, 조업 안전성 제고 측면에서 실온의 고염기성 탄산염에 의한 용해/침전법이 제시되고 있다. [6-13]

따라서 본 연구는 우선 우리 연구원에 저장 중인 석회침전 물에 존재하는 각 원소의 성분 및 조성을 분석하고, 이를 기반 으로 모의 석회침전물을 제조하여 각각 탄산염 및 질산 용액 에서 각 원소의 용해 거동 및 $\mathrm{U}$ 의 침전 제거 특성 (산성화 침 전 및 과산화수소 침전)을 규명한다. 그런 다음 실제 석회침 전물을 이용하여 U과 공존 불순물과의 공용해능 및 공침전능 을 각각 고찰하고, 이로부터 U-함유 석회침전물로부터 U을 효과적으로 제거(/회수) 처리하는 기술을 제시한다.

\section{II. 실 험}

\section{가. 석회침전물}

우리 연구원에 보관 중인 U-함유 석회침전물 (U-bearing Lime Precipitate : ULP) 내 우라늄과 공존 불순물의 성분 및 조성은 Table 1과 같다. 이는 XRF (X-Ray Flourescence spectrometry)에 의해 측정된 ULP 내 $\mathrm{Na}$ 에서 U까지 측정한 농도 중에서 U의 함량과 MCA (Multi Channel Analyzer, OXFORD TENNELEC TC702, HPGe detector)에 의해 측정된 ULP 내 우라늄 $\left.{ }^{235} \mathrm{U}, 185.7 \mathrm{KeV}\right)$ 의 함량을 서로 표준화하여 얻어진 값이다. 분석된 석회침전물의 특징으로는 저장위치 (K-1, K-2)에 따라 U의 함량이 차이가 나며 U이 무시 못 할 만 큼 함유되어 있다는 점이다. 그러므로 방사성페기물의 부피 감용차원이나 향후 처분을 위한 기준을 만족시키기 위해서는 석회침전물로부터 $\mathrm{U}$ 의 제거(/회수)가 반드시 필요함을 알 수 있다.

한편 모의 U-함유 석회침전물 (Simulated U-bearing LimePrecipitate : SLP) 은 Table 1을 기준으로 비교적 함량이 많은

Table 1. Composition and concentration of ULP.

\begin{tabular}{|c|c|c||c|c|c|}
\hline Element & $\begin{array}{c}\text { K-1, } \\
\text { wt (\%) }\end{array}$ & $\begin{array}{c}\text { K-2, } \\
\text { wt (\%) }\end{array}$ & Element & $\begin{array}{c}\text { K-1, } \\
\text { wt (\%) }\end{array}$ & $\begin{array}{c}\text { K-2, } \\
\text { wt (\%) }\end{array}$ \\
\hline $\mathrm{Na}$ & 1.01 & 0.98 & $\mathrm{Mn}$ & 0.34 & 0.11 \\
\hline $\mathrm{Mg}$ & 0.30 & 0.18 & $\mathrm{Fe}$ & 7.67 & 7.66 \\
\hline $\mathrm{Al}$ & 0.74 & 1.35 & $\mathrm{Cu}$ & 0.00 & 0.06 \\
\hline $\mathrm{Si}$ & 1.42 & 5.28 & $\mathrm{Zn}$ & 0.02 & 0.10 \\
\hline $\mathrm{P}$ & 0.11 & 0.00 & $\mathrm{As}$ & 0.00 & 0.00 \\
\hline $\mathrm{S}$ & 0.25 & 0.12 & $\mathrm{Sr}$ & 0.04 & 0.04 \\
\hline $\mathrm{Ca}$ & 13.58 & 3.99 & $\mathrm{Zr}$ & 0.19 & 0.20 \\
\hline $\mathrm{Ti}$ & 0.03 & 0.16 & $\mathrm{U}$ & 11.40 & 18.25 \\
\hline $\mathrm{Cr}$ & 0.02 & 0.03 & C, H,O etc. & 62.86 & 61.49 \\
\hline
\end{tabular}


$\mathrm{Al}, \mathrm{Fe}, \mathrm{Mg}, \mathrm{Si}, \mathrm{U}$ 등으로 구성하였으며, $\mathrm{Si}$ 를 제외하고는 모두 질산염 화합물 (nitrate)로, $0.1 \mathrm{M}$ 의 질산용액에서 이를 용해 여과한 후 $\mathrm{Ca}(\mathrm{OH})_{2}$ 를 첨가하여 금속이온들을 침전시킨다. 그 런 다음 고-액 분리하여 침전물을 건조기 (Mechanical convection oven, Kukje. Sci. Co. Ltd)에서 $80 \sim 90^{\circ} \mathrm{C}$ 로 약 4 주간 건조시킨 후 파쇄하고, 체질 (sieving, 325 mesh) 하여 준비하였다. Table 2는 SLP에 함유되어 있은 각 원소의 조성 으로, SLP $1 \mathrm{~g}$ 이 $8 \mathrm{M}$ 질산용액 $100 \mathrm{~mL}$ 에서 완전히 용해된 농 도이다.

SLP를 제조하기 위하여 사용한 각종 질산염 화합물이나 이 를 용해/침전하기 위하여 첨가한 $\mathrm{HNO}_{3}, \mathrm{Ca}(\mathrm{OH})_{2}$ 등과 실제/ 모의 U-함유 석회침전물을 용해하기 위해서 사용한 $\mathrm{Na}_{2} \mathrm{CO}_{3}$, 산화제 및 침전제로 사용한 $\mathrm{H}_{2} \mathrm{O}_{2}$ 그리고 용액 내 $\mathrm{pH}$ 를 조정 하기위하여 첨가한 $\mathrm{HNO}_{3}$ 및 $\mathrm{NaOH}$ 등은 모두 특급 시약 (Alfa Aesar, Acros Organics, Aldrich 등에서 구입)으로 추가 의 정제과정 없이 직접 사용하였다.

\section{나. 실험 방법}

실험은 모의 U-함유 석회침전물 (SLP)과 당 연구원에 보관된 실제 U-함유 석회침전물 (ULP)로 구분하여 탄산염 산화용해산성화 침전과 질산용해-과산화수소 침전 실험 모두 $25 \pm 1{ }^{\circ} \mathrm{C}$, $400 \mathrm{rpm}$ 에서 회분식으로 수행하였다. SLP의 경우 탄산염 산 화용해나 질산용해 모두 SLP를 화학저울 (Chemical balance, Precisa XT320M, Prescisa Instruments Ltd.)로 정확히 $1 \mathrm{~g}$ 씩 칭량하여 각 실험 조건에 맞추어 준비한 $100 \mathrm{~mL}$ 용액에 첨가 한 후 온도, 교반속도 및 시간 조절이 가능한 다중교반기 (Multi hot plate stirrer, Super Nuova Multiplace, Barnstead/thermolyne)를 이용하여 탄산염 산화용해는 2시 간 동안, 질산 용해는 1 시간 동안 각각 용해하였다. 한편 산성 화 침전이나 과산화수소 침전은 각각 $0.5 \mathrm{M} \mathrm{Na}_{2} \mathrm{CO}_{3}+1 \mathrm{M}$ $\mathrm{H}_{2} \mathrm{O}_{2}$ 및 $1 \mathrm{M}$ 질산에 의해 용해된 용해액을 다중교반기를 이 용하여 각각의 침전 실험 조건에서 1 시간 동안 침전시켜 수행 하였다. 반면에 ULP의 경우는 용해 시 U 및 불순물의 거동을 보다 명확히 보기 위하여 석회침전물을 $5 \mathrm{~g}$ (100 mL 용액) 으 로 증가시킨 것을 제외하고는 SLP의 경우와 동일하게 수행하 였다. 그리고 각 원소의 용해농도 및 침전율은 각각 용해 및 침전이 종료된 후 원심분리기 (Hanil-3, 한일 산업사)로 고-액

Table 2. Composition and concentration of SLP.

\begin{tabular}{|c|c|c|}
\hline \multicolumn{2}{|c|}{ Element } & Concentration, $(\mathrm{mg} / \mathrm{L})$ \\
\hline $\mathrm{Al}\left(\mathrm{NO}_{3}\right)_{3}$ & $\mathrm{Al}$ & 63 \\
\hline $\mathrm{Fe}\left(\mathrm{NO}_{3}\right)_{3}$ & $\mathrm{Fe}$ & 1,922 \\
\hline $\mathrm{Mg}\left(\mathrm{NO}_{3}\right)_{2}$ & $\mathrm{Mg}$ & 84 \\
\hline $\mathrm{SiO}_{2}$ & $\mathrm{Si}$ & 32 \\
\hline $\mathrm{UO}_{2}\left(\mathrm{NO}_{3}\right)_{2} 6 \mathrm{H}_{2} \mathrm{O}$ & $\mathrm{U}$ & 6,446 \\
\hline $\mathrm{Ca}(\mathrm{OH})_{2}$ & $\mathrm{Ca}$ & 1,535 \\
\hline
\end{tabular}

분리하여 용해액 (dissolving solution) 및 침전여액 (supernatant) 내 존재하는 금속이온의 농도를 분석하여 측정 하였다.

\section{다. 분 석}

탄산염 산화용해액이나 질산 용해액 그리고 산성화 침전이 나 과산화수소 침전 여액에 함유되어 있는 $\mathrm{U}$ 과 $\mathrm{Al}, \mathrm{Ca}, \mathrm{Cr}, \mathrm{Fe}$, $\mathrm{Mg}, \mathrm{Mo}, \mathrm{Si}, \mathrm{P}, \mathrm{Na}$ 등의 농도 분석은 $\mathrm{Na}$ (Atomic Absorption spectrophotometer, Varian AA475)를 제외하고는 모두 ICP (Inductive Coupled Plasma Spectrophotometer, ISA JobinYvon JY 50P and JY 38 Plus)를 이용하여 수행하였으며, $\mathrm{pH}$ 및 과산화수소의 농도는 각각 $\mathrm{pH}$ meter (ORION 820A+, Thermo Electronic Corporation) 및 MERCK 사의 RQflex 10을 이용하여 분석하였다. 한편 탄산염 농도는 TOC (Total organic carbon analzer, TOC-VCSH, SHIMADZU)로 TC를 측정하여 분 석하였으며, 각 원소의 침전율 (Precipitation yield, $P$ )은 식 (1) 에 의해서, 그리고 ULP의 융해율 $\left(D_{U L P}\right)$ 과 ULP 내 U의 융해율 $\left(D_{U L P-U}\right)$ 은 각각 식 (2)에 의해서 계산하였다.

$$
\begin{aligned}
& P(\%)=\left(C_{i}-C_{f}\right) / C_{i} \times 100 \\
& D_{U L P}(\%)=\left(W-W_{i}\right) / W_{i} \times 100, D_{U L P-U}(\%)=\left(M-M_{i}\right) / M_{i} \times 100
\end{aligned}
$$

여기서 $\mathrm{C}_{i}$ 및 $\mathrm{C}_{f}$ 는 각각 용해액 (탄산염/질산) 및 침전 여액 (산성화/과산화수소 침전)에 존재하고 있는 각 금속이온의 농 도 $(\mathrm{mg} / \mathrm{L})$ 를 의미한다. 그리고 $W_{i}$ 및 $W$ 는 각각 ULP 초기 량 및 여과 건조한 불용해 ULP의 량 $(\mathrm{g})$ 를 의미하며, Mi 및 $\mathrm{M}$ 은 각각 $\mathrm{MCA}$ 로 측정한 $\mathrm{ULP}$ 내 함유된 초기 $\mathrm{U}$ 의 농도 (counter) 및 여과 건조한 불용해 ULP 내 U의 농도를 의미한다.

\section{III. 결과 및 고찰}

\section{가. 모의 석회침전물 (SLP)}

Figure 1은 $0.5 \mathrm{M} \mathrm{Na}_{2} \mathrm{CO}_{3}+\mathrm{x} \mathrm{M} \mathrm{H} \mathrm{H}_{2}$ 계에서 $\mathrm{H}_{2} \mathrm{O}_{2}$ 농도 변화에 따른 각 원소의 용해농도이다. 이때 용해액 내 $\mathrm{pH}$ 는 $\mathrm{H}_{2} \mathrm{O}_{2}$ 농도 증가에 따라 9.28 8.91로 다소 감소하였다. U의 경우 $\mathrm{H}_{2} \mathrm{O}_{2}$ 농도 증가에 따라 $0.5 \mathrm{M}$ 까지는 증가하다가 일정 하게 유지되고 있다. $\mathrm{UO}_{2}$ 분말의 경우 $0.5 \mathrm{M} \mathrm{Na}_{2} \mathrm{CO}_{3}+1 \mathrm{M}$ $\mathrm{H}_{2} \mathrm{O}_{2}$ 에서 약 $50 \pm 1 \mathrm{~g} / \mathrm{L}$ 까지 용해되어 [14], SLP 내 U의 농 도가 $6,446 \mathrm{mg} / \mathrm{L}$ 임을 고려하여 볼 때 $1 \mathrm{M} \mathrm{H}_{2} \mathrm{O}_{2}$ 에서 거의 $100 \%$ 용해될 것으로 예측하였는데, $2 \mathrm{M} \mathrm{H}_{2} \mathrm{O}_{2}$ 에서도 약 $96 \%(6,171 \mathrm{mg} / \mathrm{L})$ 만이 용해되었다. 이는 SLP에 함유되어 있는 $\mathrm{U}$ 이 $\mathrm{UO}_{2}\left(\mathrm{NO}_{3}\right)_{2}+\mathrm{Ca}(\mathrm{OH})_{2} \Leftrightarrow \mathrm{CaU}_{2} \mathrm{O}_{7}+2 \mathrm{HNO}_{3}$ 에 의 


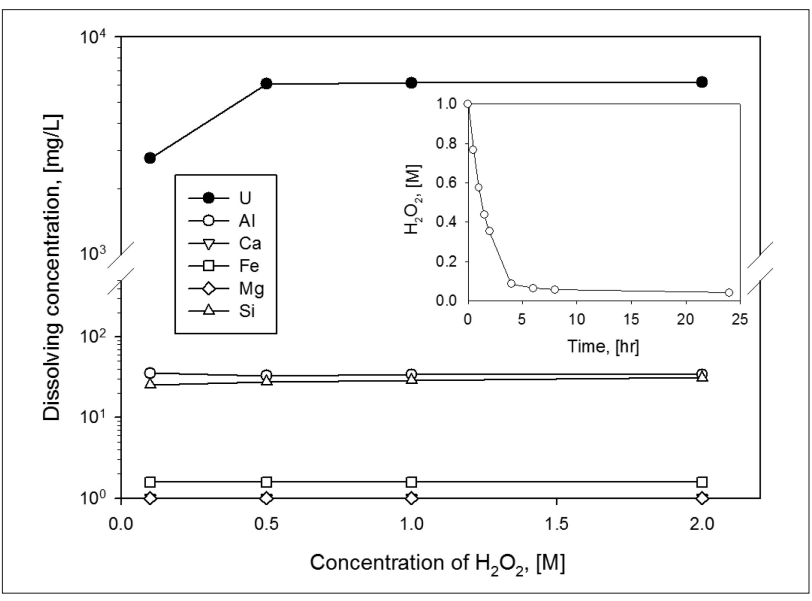

Fig. 1. Dissolving concentration of each element with concentration of $\mathrm{H}_{2} \mathrm{O}_{2}$ in $0.5 \mathrm{M} \mathrm{Na}_{2} \mathrm{CO}_{3}+\mathrm{xM} \mathrm{H}_{2} \mathrm{O}_{2}$ system.

해 $\mathrm{CaU}_{2} \mathrm{O}_{7}$ 로 존재하여, $\mathrm{UO}_{2}$ 분말과는 탄산염 용액에서의 용해도가 서로 다른데 기인하는 것 같다. 한편 $\mathrm{Si}$ 는 $\mathrm{H}_{2} \mathrm{O}_{2}$ 농 도에 따라 용해농도가 $26 \sim 31 \mathrm{mg} / \mathrm{L}$ 로, $\mathrm{Al}$ 은 $34 \pm 1 \mathrm{mg} / \mathrm{L}$ 로 용해되어 $\mathrm{H}_{2} \mathrm{O}_{2}$ 농도에 별 영향이 없는 것 같다. 그리고 $\mathrm{Ca}$, $\mathrm{Fe}, \mathrm{Mg}$ 등은 $2 \mathrm{mg} / \mathrm{L}$ 이하로 거의 용해되지 않고 있다. 이는 $\mathrm{SLP}$ 에서 $\mathrm{Ca}$ 는 $\mathrm{Ca}(\mathrm{OH})_{2}$ 로, $\mathrm{Fe}$ 는 $\mathrm{Fe}\left(\mathrm{NO}_{3}\right)_{3}+\mathrm{Ca}(\mathrm{OH})_{2} \Leftrightarrow$ $\mathrm{Fe}(\mathrm{OH})_{3}+\mathrm{Ca}\left(\mathrm{NO}_{3}\right)_{2}$ 에 의해 $\mathrm{Fe}(\mathrm{OH})_{3}$ 로, $\mathrm{Mg}$ 는 $\mathrm{Mg}\left(\mathrm{NO}_{3}\right)_{2}+$ $\mathrm{Ca}(\mathrm{OH})_{2} \Leftrightarrow \mathrm{Mg}(\mathrm{OH})_{2}+\mathrm{Ca}\left(\mathrm{NO}_{3}\right)_{2}$ 에 의해 $\mathrm{Mg}(\mathrm{OH})_{2}$ 등의 수 산화물 형태로 존재하는데, 이들은 탄산염 용액에서 용해도 가 매우 낮기 때문이다. [15] 한편 Figure 1의 작은 그림은 SLP의 탄산염 산화용해의 경우 분해되는 $\mathrm{H}_{2} \mathrm{O}_{2}$ 의 농도 변화 를 나타낸 것으로 용해시간 증가에 따라 급격히 감소하고 있으며, 8시간이 경과된 후 $0.05 \sim 0.06 \mathrm{M}$ 까지 감소되고 있 다. 이는 고염기성 용액에서 $\mathrm{H}_{2} \mathrm{O}_{2}$ 의 자체분해 (self decomposition) 및 $\mathrm{U}, \mathrm{Al}, \mathrm{Si}$ 등의 산화 용해제로서 소모되 기 때문이다. [16]

Figure 2는 x M Na $2 \mathrm{CO}_{3}+1 \mathrm{M} \mathrm{H}_{2} \mathrm{O}_{2}$ 계에서 $\mathrm{Na}_{2} \mathrm{CO}_{3}$ 농도 변화에 따른 각 원소의 용해농도이며, $\mathrm{Na}_{2} \mathrm{CO}_{3}$ 농도 증가에 따라 용해액의 $\mathrm{pH}$ 는 9.89 10.83 이었다. U, Al, Si 등은 $\mathrm{Na}_{2} \mathrm{CO}_{3}$ 농도 증가에 따라 증가하고 있으며, $1.5 \mathrm{M} \mathrm{Na}_{2} \mathrm{CO}_{3}$ 에서 U은 $6,415 \mathrm{mg} / \mathrm{L}, \mathrm{Al}$ 은 $60 \mathrm{mg} / \mathrm{L}, \mathrm{Si}$ 는 $32 \mathrm{mg} / \mathrm{L}$ 로 거의 전량이 용해되고 있다. $\mathrm{Al}$ 및 $\mathrm{Si}$ 의 경우 $\mathrm{Na}_{2} \mathrm{CO}_{3}+\mathrm{H}_{2} \mathrm{O}_{2}$ 용액 계에서 $\mathrm{Al}$ 과 $\mathrm{Si}$ 의 산화물 $\left(\mathrm{Al}_{2} \mathrm{O}_{3}, \mathrm{SiO}_{2}\right.$ 등)이 거의 용해되지 않는 것과는 다른 결과로서 [17], SLP에 함유된 $\mathrm{Al}$ 및 Si가 $\mathrm{Ca}(\mathrm{OH})_{2}$ 침전 시 고염기성 용액에서 높은 용해도를 갖는 $\mathrm{Al}(\mathrm{OH})_{3}$ 나 $\mathrm{Si}(\mathrm{OH})_{4}$ 등의 수화물 형태로 침전된데 기인하는 것 같다. [15] 반면에 $\mathrm{Ca}, \mathrm{Fe}, \mathrm{Mg}$ 등은 $1 \mathrm{M} \mathrm{Na}_{2} \mathrm{CO}_{3}$ 이하에서 는 $2 \mathrm{mg} / \mathrm{L}$ 이하로 거의 불용해 되지만, $1.5 \mathrm{M}$ 에서는 $\mathrm{Ca}$, $\mathrm{Mg}$ 등이 다소 용해되고 있다.
Figure 3은 $0.5 \mathrm{M} \mathrm{Na}_{2} \mathrm{CO}_{3}+1 \mathrm{M} \mathrm{H}_{2} \mathrm{O}_{2}$ 계에서 용액 내 $\mathrm{pH}$ 변화에 따른 각 원소의 용해농도이다. $\mathrm{U}$ 은 $\mathrm{pH}$ 가 증가함에 따라 용해농도가 급격히 증가하고 있으며, $\mathrm{pH} 4$ 에서는 85 $\mathrm{mg} / \mathrm{L}$ 가 용해되는 데 반하여 $\mathrm{pH} 9$ 이상에서는 $6,350 \pm 100$ $\mathrm{mg} / \mathrm{L}$ 가 용해되고 있다. 이는 고염기성 $\mathrm{Na}_{2} \mathrm{CO}_{3}-\mathrm{H}_{2} \mathrm{O}_{2}$ 계에서 $\mathrm{U}$ 의 용해도가 높기 때문이다. [14] 한편 $\mathrm{Ca}, \mathrm{Fe}$ 및 $\mathrm{Mg}$ 등은 $\mathrm{U}$ 의 용해거동과는 다르게 $\mathrm{pH}$ 중가에 따라 용해농도가 급격 히 감소하고 있다. 이중 $\mathrm{Fe}$ 및 $\mathrm{Mg}$ 는 각각 $\mathrm{pH} 4$ 및 $\mathrm{pH} 11$ 이 상에서, $\mathrm{Ca}$ 는 $\mathrm{pH} 8$ 이상에서 $2 \mathrm{mg} / \mathrm{L}$ 이하로 거의 불용해 되고 있다. 반면에 $\mathrm{Al}$ 은 $\mathrm{pH}$ 증가에 따라 감소하여 $\mathrm{pH}$ 7 8 정도에서 최저의 용해농도 (약 $3 \mathrm{mg} / \mathrm{L}$ )를 보이다가 $\mathrm{pH} 11$ 이상에서 $48 \mathrm{mg} / \mathrm{L}$ 정도로 재용해되고 있다. 그리고 Si는 U 과 같이 $\mathrm{pH}$ 증가에 따라 다소 증가하나 $\mathrm{pH} 8$ 이상에서 30 $\pm 5 \mathrm{mg} / \mathrm{L}$ 로 거의 일정하게 용해되고 있다. 그러므로 $\mathrm{pH} 10$ 정도에서 조업하면 비록 $\mathrm{Al}, \mathrm{Si}$ 등이 U과 다소 공용해되지만

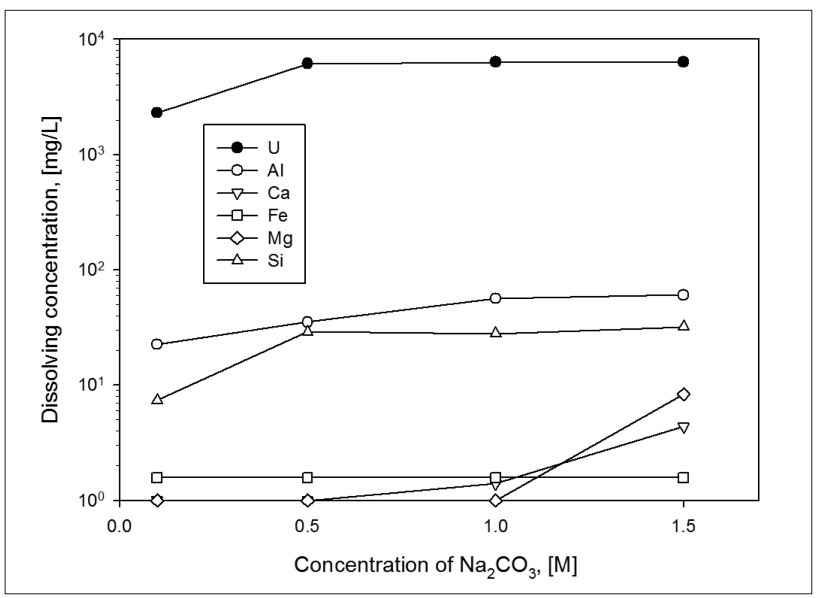

Fig. 2. Dissolving concentration of each element with $\mathrm{Na}_{2} \mathrm{CO}_{3}$ concentration in $x M \mathrm{Na}_{2} \mathrm{CO}_{3}+1 \mathrm{M} \mathrm{H}_{2} \mathrm{O}_{2}$ system.

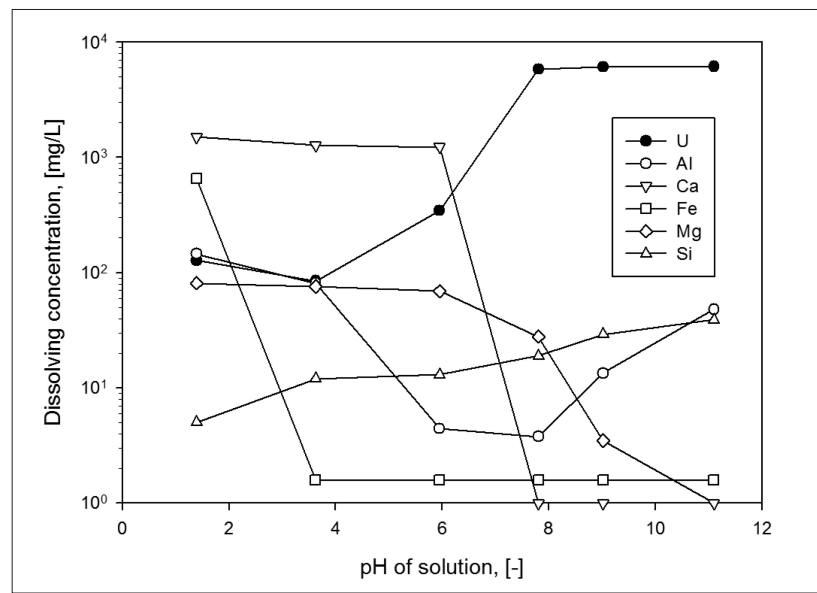

Fig. 3. Dissolving concentration of each element with $\mathrm{pH}$ of the solution at $0.5 \mathrm{M} \mathrm{Na}_{2} \mathrm{CO}_{3}+1 \mathrm{M} \mathrm{H}_{2} \mathrm{O}_{2}$ system. 
$\mathrm{Ca}, \mathrm{Fe}, \mathrm{Mg}$ 등 특히 ULP 내 다량 함유된 $\mathrm{Ca}, \mathrm{Fe}$ 을 U으로부 터 완전히 제거할 수 있어 방사성폐기물의 발생량을 대폭 저감화 시킬 수 있을 것으로 판단된다.

Figure 4에는 $0.5 \mathrm{M} \mathrm{Na}_{2} \mathrm{CO}_{3}+1 \mathrm{M} \mathrm{H}_{2} \mathrm{O}_{2}$ 에서 산화용해 여 과한 용액 $\left(\mathrm{H}_{2} \mathrm{O}_{2}\right.$ 농도 : $5 \mathrm{mg} / \mathrm{L}$ 이하)을 산성화 침전할 경우 $\mathrm{pH}$ 변화에 따른 $\mathrm{U}$ 의 침전율을 나타내었다. $\mathrm{U}$ 의 산성화 침 전은 탄산염 $-\mathrm{H}_{2} \mathrm{O}_{2}$ 계에서 식 (3)과 같이 용해된 uranyl peroxo carbonate 착물이온 $\left(\left[\mathrm{UO}_{2}\left(\mathrm{O}_{2}\right)_{\mathrm{x}}\left(\mathrm{CO}_{3}\right)_{\mathrm{y}}\right]^{2-2 \mathrm{x}-2 \mathrm{y}}\right)$ 이 질산 첨가에 의해 식 (4)로 이루어지며 $[6,7,18]$

$$
\begin{aligned}
& \mathrm{UO}_{2}+\mathrm{xCO}_{3}^{2-}+\mathrm{yH}_{2} \mathrm{O}+2 \mathrm{yOH}^{-} \\
& \Rightarrow\left[\mathrm{UO}_{2}\left(\mathrm{O}_{2}\right)_{\mathrm{x}}\left(\mathrm{CO}_{3}\right)_{\mathrm{y}}\right]^{2-2 \mathrm{x}-2 \mathrm{y}}+2 \mathrm{yH}_{2} \mathrm{O}+2 \mathrm{e}^{-} \\
& \text {drying } \\
& {\left[\mathrm{UO}_{2}\left(\mathrm{O}_{2}\right) \mathrm{x}\left(\mathrm{CO}_{3}\right)_{\mathrm{y}}\right]^{2-2 \mathrm{x}-2 \mathrm{y}}+\mathrm{mH}^{+}+2 \mathrm{yH}_{2} \mathrm{O} \Rightarrow \mathrm{UO}_{4} \cdot 4 \mathrm{H}_{2} \mathrm{O}} \\
& +\mathrm{yH}_{2} \mathrm{CO}_{3} \Rightarrow \mathrm{UO}_{4} \cdot 2 \mathrm{H}_{2} \mathrm{O}
\end{aligned}
$$

침전율은 $\mathrm{pH}$ 증가에 따라 $\mathrm{pH} 5$ 이상에서부터 급격히 감 소하다가 $\mathrm{pH} 9$ 이상에서는 침전이 거의 일어나지 않고 있 다. 이는 $\mathrm{pH} 9$ 이상의 탄산염 계에서 $\mathrm{U}$ 의 용해도가 매우 크 기 때문이다. [14,17] 그리고 본 그림에는 나타내지 않았으 나 U과 공용해되는 $\mathrm{Al}(45 \mathrm{mg} / \mathrm{L}), \mathrm{Si}(31 \mathrm{mg} / \mathrm{L})$ 는 $\mathrm{pH}$ 가 증 가함에 따라 침전율이 다소 감소하는 경향으로 $\mathrm{pH} 1$ 에서 $\mathrm{Al}$ 및 $\mathrm{Si}$ 는 각각 $10 \%, 5 \%$ 이하로, $\mathrm{pH} 5$ 이상에서는 침전이 일 어나지 않았다. 한편 $\mathrm{pH}$ 변화에 따른 carbonate 농도 변화 는 $\mathrm{U}$ 의 침전율과는 다르게 $\mathrm{pH}$ 가 증가함에 따라 증가하고 있으며, $\mathrm{pH} 4$ 이하에서는 carbonate가 거의 존재하지 않고 있다. 이는 uranyl peroxocarbonate 착물의 carbonate 성분 $\left(\mathrm{H}_{2} \mathrm{CO}_{3}, \mathrm{HCO}_{3}^{-}\right.$및 $\mathrm{CO}_{3}^{-2}$ 등)이 $\mathrm{pH}$ 에 따라 다양하게 존재하 며 산성화에 의해 carbonic acid로 변환되고, carbonic acid 는 용액 상에서 매우 불안정하여 쉽게 $\mathrm{CO}_{2}$ 로 재변환 되어 [19] 대기 중으로 방출되기 때문에 낮은 $\mathrm{pH}$ 영역에서는 carbonate가 거의 없는 것 같다. 이로부터 석회침전물을 탄 산염에서 산화용해하여 $\mathrm{U}$ 을 제거(/회수)할 경우 용해는 0.5 $\mathrm{M} \mathrm{Na} \mathrm{CO}_{3}+1 \mathrm{M} \mathrm{H}_{2} \mathrm{O}_{2}$ 에서, 침전은 $\mathrm{pH} 3$ 정도에서 산성화 하여 수행하는 것이 효과적이다.

Figure 5는 질산농도 변화에 따른 SLP 내 각 원소의 용해 농도이다. 질산농도 증가에 따라 각 원소의 용해농도가 증 가하고 있으며, 질산농도 $1 \mathrm{M}$ 이상에는 $\mathrm{U}$ 은 $6,450 \pm 50$ $\mathrm{mg} / \mathrm{L}$ 로 SLP에 함유되어 있는 우라늄의 $99 \%$ 이상, $\mathrm{Ca}$ 와 $\mathrm{Fe}$ 는 각각 $1,500 \pm 50 \mathrm{mg} / \mathrm{L}, 1,900 \pm 100 \mathrm{mg} / \mathrm{L}$ 로 $98 \%$ 이상 그 리고 $\mathrm{Al}, \mathrm{Mg}, \mathrm{Si}$ 는 거의 모두가 용해되고 있다. 그러므로 $\mathrm{U}$ 과 기타 원소와의 공용해를 최소화하기 위해서는 질산 농도

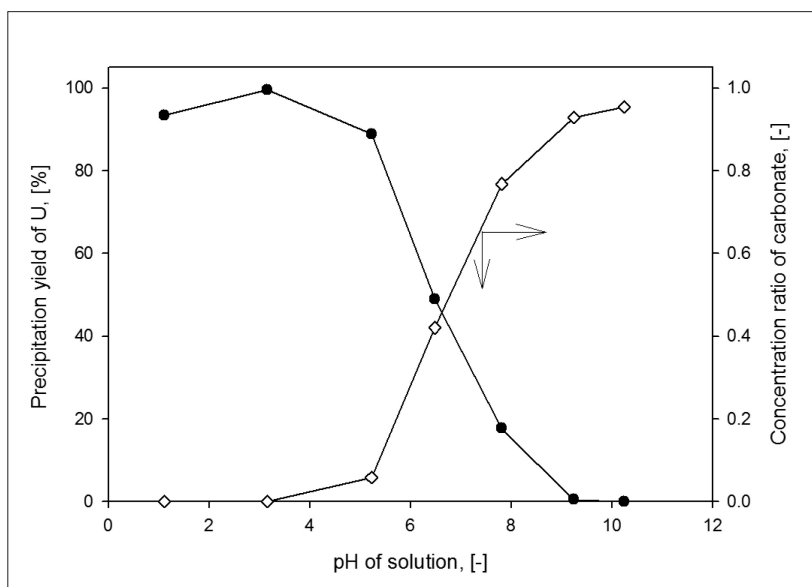

Fig. 4. Uranium precipitation yield and carbonate concentration ratio with $\mathrm{pH}$ of solution after acidified precipitation in dissolving solution by $0.5 \mathrm{M} \mathrm{Na}_{2} \mathrm{CO}_{3}+1 \mathrm{M} \mathrm{H}_{2} \mathrm{O}_{2}$.

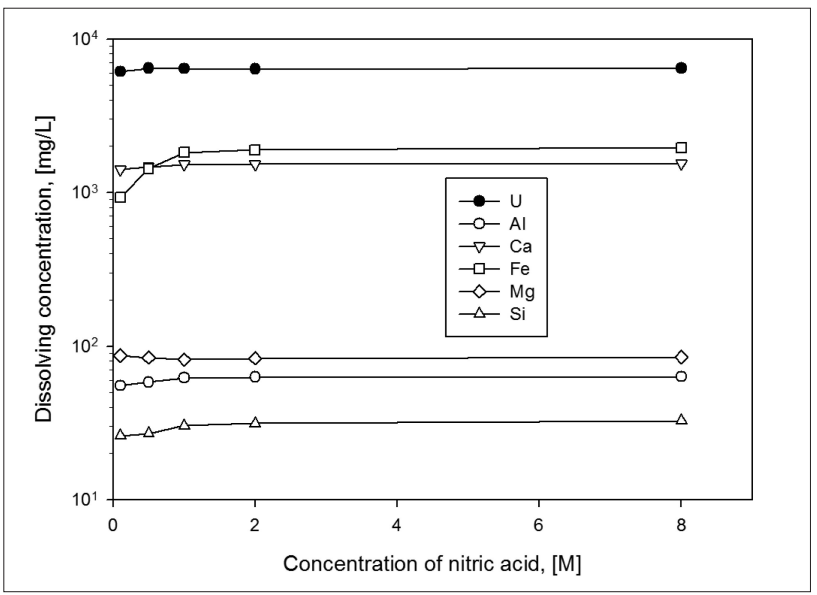

Fig. 5. Dissolving concentration of each element with concentration of nitric acid.

를 다소 낮추는 것이 바람직하지만, 이 경우 $\mathrm{U}$ 의 용해농도 $(6,019 \mathrm{mg} / \mathrm{L})$ 도 다소 감소하게 되어 $\mathrm{U}$ 의 제거(/회수) 관점 에서 효과적이지 못하다.

Figure 6 은 $1 \mathrm{M} \mathrm{HNO}_{3}$ 에서 용해 여과한 용액을 대상으로 $\mathrm{H}_{2} \mathrm{O}_{2}$ 의 첨가유무 및 $\mathrm{pH}$ 변화에 따른 각 원소의 침전율이다. $\mathrm{H}_{2} \mathrm{O}_{2}$ 를 첨가하지 않는 경우 $\mathrm{U}$ 의 침전은 $\mathrm{pH} 3 \sim 4$ 이하에서 는 거의 이루어지지 않고 있으나, $\mathrm{pH}$ 6 7 이상에서는 가수 분해 등으로 $\mathrm{U}$ 이 거의 모두 침전되고 있다. 그러나 $\mathrm{H}_{2} \mathrm{O}_{2}$ 를 첨가할 경우 $\left(\left[\mathrm{H}_{2} \mathrm{O}_{2}\right] /[\mathrm{U}]\right.$ 몰 농도비 $\left.=3.7\right) \mathrm{pH}$ 증가에 따라 각 원소의 침전이 증가되고 있으며, $\mathrm{U}$ 은 $\mathrm{pH} 2$ 이상에서 $\mathrm{Fe}$ 은 4 이상에서, 기타 $\mathrm{Ca}, \mathrm{Mg}$ 는 9 이상에서 거의 모두 침전되고 있다. 이때 U의 침전 반응은 다음과 같다. $[20,21]$

$$
\begin{aligned}
& \mathrm{UO}_{2}\left(\mathrm{NO}_{3}\right)_{2}+\mathrm{H}_{2} \mathrm{O}_{2}+4 \mathrm{H}_{2} \mathrm{O} \text { drying } \\
& \quad \Rightarrow \mathrm{UO}_{4} \cdot 4 \mathrm{H}_{2} \mathrm{O}+2 \mathrm{HNO}_{3} \Rightarrow \mathrm{UO}_{4} \cdot 2 \mathrm{H}_{2} \mathrm{O}
\end{aligned}
$$


Figure 7은 Figure 6과 동일한 용해액을 $\mathrm{pH}$ 2로 조정한 후 첨가한 $\mathrm{H}_{2} \mathrm{O}_{2}$ 농도 변화에 따른 각 원소의 침전율이다. $\left[\mathrm{H}_{2} \mathrm{O}_{2}\right] /[\mathrm{U}]$ 의 몰 농도 비 증가에 따라 증가하는 경향으로 $\mathrm{U}$, $\mathrm{Al}, \mathrm{Fe}$ 등은 $\left[\mathrm{H}_{2} \mathrm{O}_{2}\right] /[\mathrm{U}]$ 의 몰 농도 비 2 이상에서 거의 모두 침전됨을 알 수 있다. 이로부터 석회침전물을 질산에 용해 하여 $\mathrm{U}$ 을 제거(/회수)할 경우 용해는 $1 \mathrm{M} \mathrm{HNO}_{3}$ 에서, 침전은 $\left[\mathrm{H}_{2} \mathrm{O}_{2}\right] /[\mathrm{U}]$ 의 몰 농도 비는 2 정도 그리고 침전용액 내 $\mathrm{pH}$ 는 2 3 에서 수행하는 것이 바람직하다.

\section{나. 실제 석회침전물 (ULP : $\mathrm{K}-1, \mathrm{~K}-2$ )}

Table 3 는 우리 연구원에 저장된 ULP (K-1, K-2)의 용해

Table 3. Dissolution yield (\%) of $U$ in the U-bearing Lime-Precipitate.

\begin{tabular}{|c|c|c|c|c|}
\hline \multirow{2}{*}{} & \multicolumn{2}{|c|}{ ULP dissolution, (\%) } & \multicolumn{2}{c|}{ Dissolution yield of U in ULP (\%) } \\
\cline { 2 - 5 } & carbonate sol. & nitric acid sol. & carbonate sol. & nitric acid sol. \\
\hline K-1 & 16.6 & 88.6 & 86.7 & 97.6 \\
\hline K-2 & 25.9 & 51.9 & 89.0 & 98.6 \\
\hline
\end{tabular}

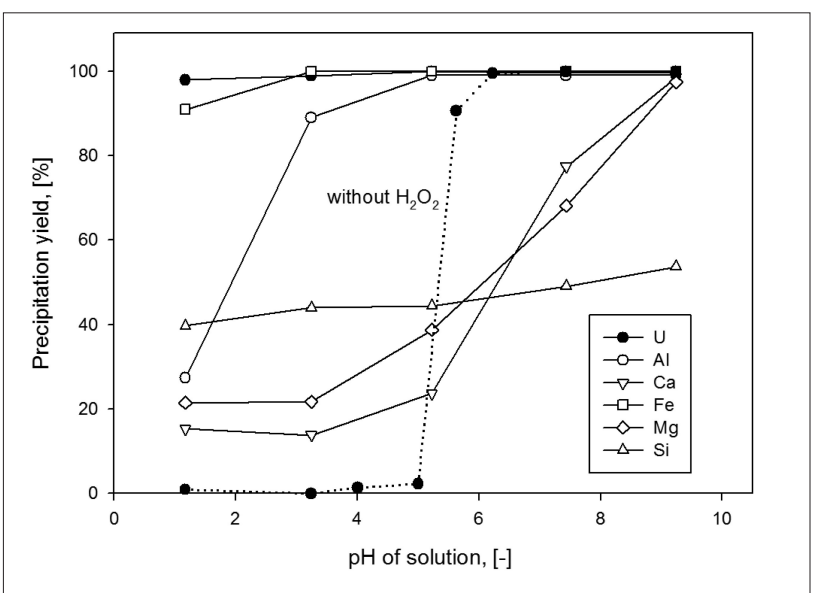

Fig. 6. Precipitation yield of uranium with $\mathrm{pH}$ of solution after precipitation with and without $\mathrm{H}_{2} \mathrm{O}_{2}$ in dissolving soltion by $1 \mathrm{M}$ $\mathrm{HNO}_{3}$.

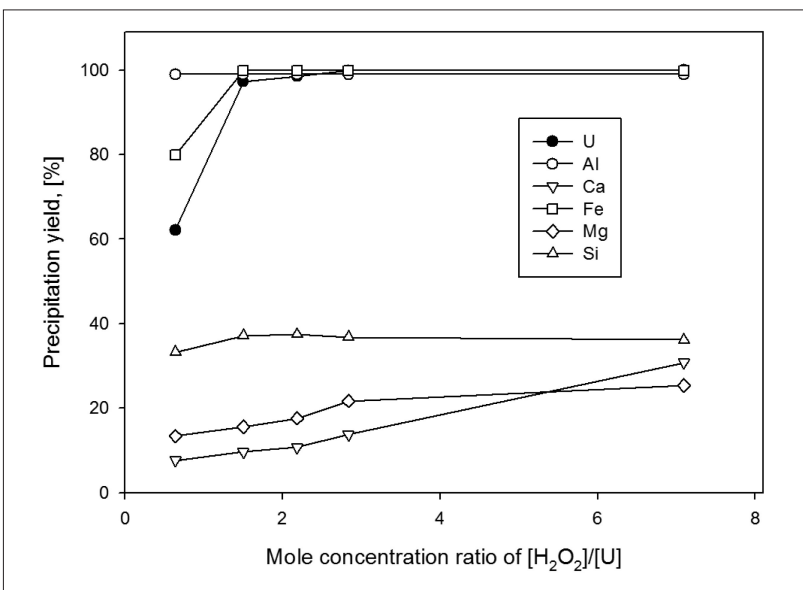

Fig. 7. Precipitation yield of each element with mole concentration ratio of $\mathrm{H}_{2} \mathrm{O}_{2}$ to uranium in $1 \mathrm{M}$ nitric acid dissolving solution.
및 $\mathrm{U}$ 의 침전 제거(/회수)에 앞서 $\mathrm{K}-1, \mathrm{~K}-2$ 각각 $5 \mathrm{~g}$ 을 100 $\mathrm{mL}$ 의 탄산염 용액 $\left(0.5 \mathrm{M} \mathrm{Na}_{2} \mathrm{CO}_{3}+1 \mathrm{M} \mathrm{H}_{2} \mathrm{O}_{2}\right)$ 및 질산 (1 $\mathrm{M} \mathrm{HNO}_{3}$ ) 용액으로 용해할 때 ULP 자체의 용해율과 ULP 내 함유되어 있는 U의 용해율을 각각 나타내었다.

$\mathrm{ULP}$ 의 용해율 및 U의 용해율 모두 질산용액에서 보다 많 이 용해되며, ULP의 용해는 탄산염 산화용해 시 약 20 $30 \%$ 용해되고, 질산에서는 약 $55 \%$ 에서 최대 $89 \%$ 까지 용해 되었다. 이로부터 ULP 내에는 탄산염이나 질산용액에 의해 용해되지 않는 상당량의 불용해 물질이 함유되어 있음을 알 수 있다. 그리고 ULP 내 함유되어 있는 U은 탄산염 산화용 해에서 87 89\%, 질산용해에서는 98 99\% 용해가 가능함 을 알 수 있다.

Figure 8은 K-1, K-2 각각 $5 \mathrm{~g}$ 을 $0.5 \mathrm{M} \mathrm{Na}_{2} \mathrm{CO}_{3}+1 \mathrm{M}$ $\mathrm{H}_{2} \mathrm{O}_{2}$ 용액 $100 \mathrm{~mL}$ 에 용해할 때 각 원소의 용해농도이다. 이 때 용액 내 $\mathrm{pH}$ 는 K-1은 $11.55, \mathrm{~K}-2$ 는 11.16 이었다. K-1, K2 경우 모두 $\mathrm{Al}, \mathrm{Mg} . \mathrm{Si}, \mathrm{U}, \mathrm{Na}$ 등이 용해되었으며, 기타 $\mathrm{Ca}$, $\mathrm{Cr}, \mathrm{Fe}, \mathrm{Mo}, \mathrm{P}$ (약 $10 \mathrm{mg} / \mathrm{L}$ ) 등은 $5 \mathrm{mg} / \mathrm{L}$ 이하로 거의 불용 해 되고 있다. U의 경우 K-1은 약 $3,600 \mathrm{mg} / \mathrm{L}, \mathrm{K}-2$ 는 8,100 $\mathrm{mg} / \mathrm{L}$ 가, $\mathrm{Na}$ 은 $0.5 \mathrm{M} \mathrm{Na}_{2} \mathrm{CO}_{3}$ 용해매질에 기인하여 $\mathrm{K}-1, \mathrm{~K}-2$ 모두 $20 \mathrm{~g} / \mathrm{L}$ 이상이, 기타 $\mathrm{Al}, \mathrm{Mg} . \mathrm{Si}$ 등은 $60 \mathrm{mg} / \mathrm{L}$ 이하가 용해되었다. Figure 9는 Figure 8의 용해액에 질산을 첨가하 여 $\mathrm{pH} 3$ (K-1의 $\mathrm{pH}$ 는 $2.79, \mathrm{~K}-2$ 는 2.98) 으로 산성화시켜 침전할 경우 각 원소의 침전율이다. $\mathrm{Al}, \mathrm{P}, \mathrm{Si}, \mathrm{U}, \mathrm{Na}$ 이외의 원소는 용해액에서의 이들의 농도가 $5 \mathrm{mg} / \mathrm{L}$ 이하로 매우 낮 아 고려하지 않았다. $\mathrm{Na}$ 의 경우 산성화에 의해 거의 침전이 이루어지지 않고 있으며, $\mathrm{Al}, \mathrm{P}, \mathrm{Si}$ 의 경우 식(1)에 의거 $\mathrm{U}$ 과 의 공침전율이 큰 것으로 나타나나, 침전물 내 함유되어 있 는 이들의 농도는 U 농도 $(\mathrm{K}-1: 3,300 \mathrm{mg} / \mathrm{L}, \mathrm{K}-2: 7,820$ $\mathrm{mg} / \mathrm{L}$ )와 비교하여 비교적 적어 산성화 침전에 의한 $\mathrm{U}$ 의 제

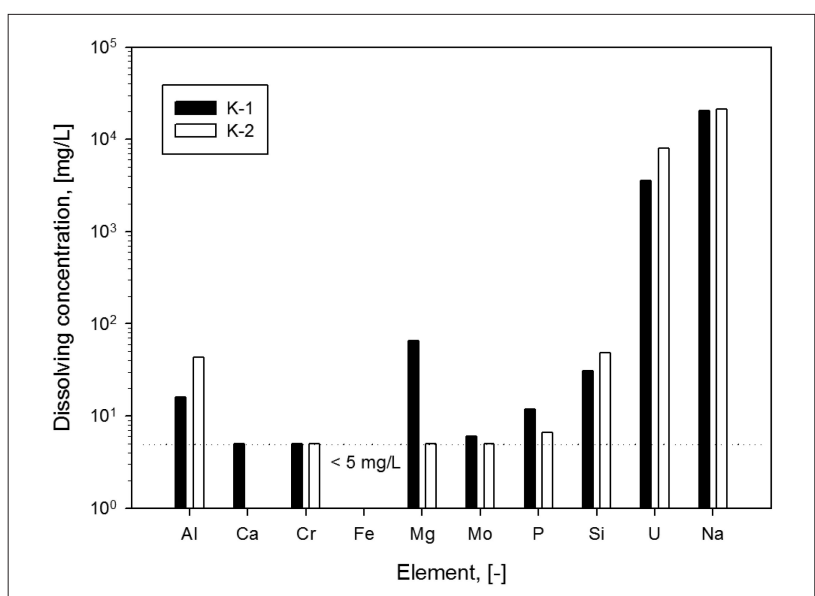

Fig. 8. Concentration of each elment in ULP solution dissolved by $0.5 \mathrm{M} \mathrm{Na}_{2} \mathrm{CO}_{3}+1 \mathrm{M} \mathrm{H}_{2} \mathrm{O}_{2}$. 
거(/회수)에 별 문제가 없을 것으로 보인다.

Figure 10은 K-1, K-2 (각각 $5 \mathrm{~g}$ )를 $1 \mathrm{M} \mathrm{HNO}_{3}$ 용액 (100 $\mathrm{mL}$ )에서 용해할 때 각 원소의 용해농도이다. $0.5 \mathrm{M} \mathrm{Na}_{2} \mathrm{CO}_{3}$ $+1 \mathrm{M} \mathrm{H}_{2} \mathrm{O}_{2}$ 용액에서의 용해와는 다르게 $\mathrm{Cr}, \mathrm{Mo}, \mathrm{P}$ 를 제외 하고 $\mathrm{Al}(\mathrm{K}-1: 410 \mathrm{mg} / \mathrm{L}, \mathrm{K}-2: 280 \mathrm{mg} / \mathrm{L}), \mathrm{Ca}(9,300 \mathrm{mg} / \mathrm{L}$, 2,800 mg/L), Fe (3,500 mg/L, 1,100 mg/L), Mg (290 mg/L, $77 \mathrm{mg} / \mathrm{L}), \mathrm{Si}(650 \mathrm{mg} / \mathrm{L}, 93 \mathrm{mg} / \mathrm{L}), \mathrm{Na}(90 \mathrm{mg} / \mathrm{L}$, $160 \mathrm{mg} / \mathrm{L})$ 등이 U $(4,500 \mathrm{mg} / \mathrm{L}, 8,800 \mathrm{mg} / \mathrm{L})$ 과 함께 용해 되었다. 그리고 Figure 11은 Figure 10의 용해액에 $0.1 \mathrm{M}$ $\mathrm{H}_{2} \mathrm{O}_{2}$ 를 첨가한 후 $\mathrm{NaOH}$ 로 $\mathrm{pH} 2$ (K-1의 $\mathrm{pH}$ 는 $1.89, \mathrm{~K}-2$ 는 $1.50)$ 로 조정하여 침전한 경우 각 원소의 침전율이다. U과 공침되는 $\mathrm{Al}, \mathrm{Ca}, \mathrm{Fe}, \mathrm{Mg}, \mathrm{Si}$ 의 Figure 10 의 용해액 내 이들 의 농도가 높아 침전율이 적은 것으로 나타났으나, 과산화 수소 침전에 의한 $\mathrm{UO}_{4}$ 의 침전 시 $\mathrm{K}-1, \mathrm{~K}-2$ 에 관계없이 $\mathrm{Al}$ 은 최대 $38 \mathrm{mg} / \mathrm{L}, \mathrm{Ca}$ 은 $600 \mathrm{mg} / \mathrm{L}, \mathrm{Fe}$ 은 $200 \mathrm{mg} / \mathrm{L}, \mathrm{Si}$ 는 200

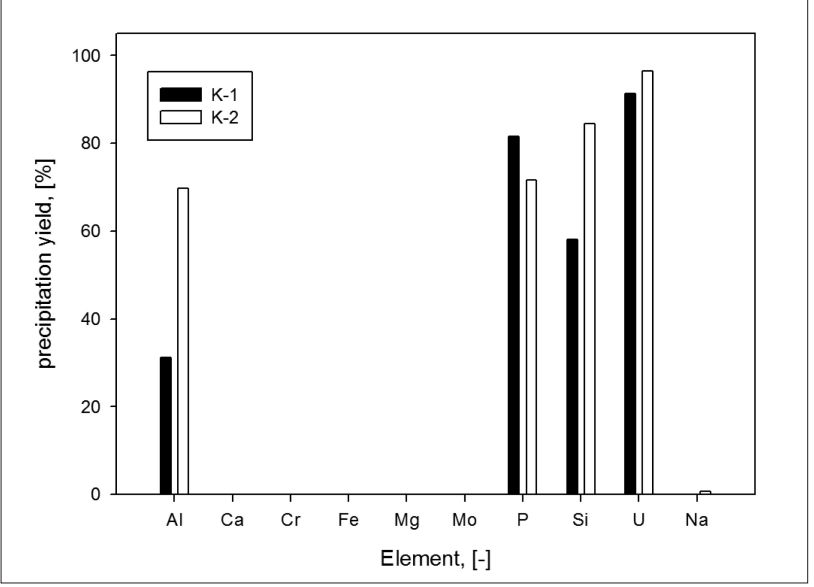

Fig. 9. Acidified precipitation yield of each element at $\mathrm{pH} 3$ in ULP solution dissolved by $0.5 \mathrm{M} \mathrm{Na}_{2} \mathrm{CO}_{3}+1 \mathrm{M} \mathrm{H}_{2} \mathrm{O}_{2}$.

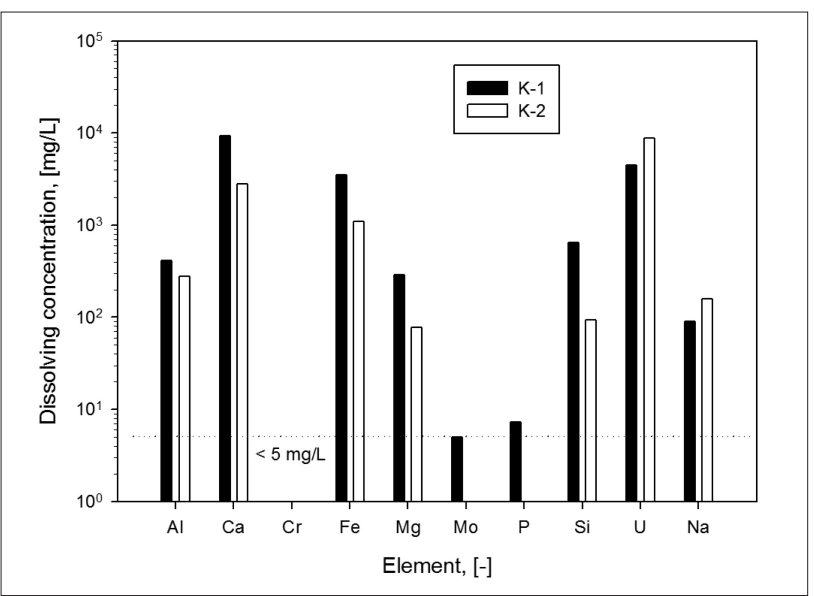

Fig. 10. Concentration of each element in RLP solution dissolved by $1 \mathrm{M}$ nitric acid. $\mathrm{mg} / \mathrm{L}$ 등 상당량이 U과 함께 침전물에 공존하여 U의 선택적 제거나 고순도 $\mathrm{U}$ 의 회수는 어려울 것으로 판단된다.

Figure 12는 K-2 침전물의 건조 조건에 따른 XRD data 이 다. Figure 12-(a)는 Figure 9의 산성화 침전물로 $55^{\circ} \mathrm{C}$ 에서 12 시간 건조한 것으로 $\mathrm{UO}_{4} \cdot 4 \mathrm{H}_{2} \mathrm{O}$ (JSPDS 49-1821, studtite)로, Figure 12-(b)는 Figure 12-(a)와 같은 침전물을 $80^{\circ} \mathrm{C}$ 에서 48 시간 건조한 것으로 $\mathrm{UO}_{4} \cdot 2 \mathrm{H}_{2} \mathrm{O}$ (JCPDS 350571, metastudtite)로 각각 나타났다. 반면에 Figure 12-(c) 는 Figure 11 의 과산화수소 침전물로 $55^{\circ} \mathrm{C}$ 에서 12 시간 건조

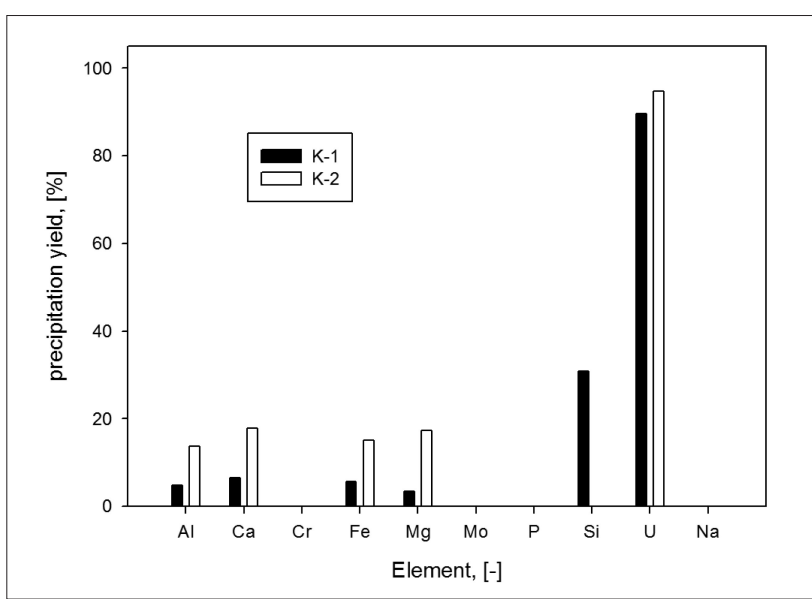

Fig. 11. Precipitation yield of each element with $0.1 \mathrm{M} \mathrm{H}_{2} \mathrm{O}_{2}$ and pH 2 in ULP solution dissolved by $1 \mathrm{M}$ nitric acid.

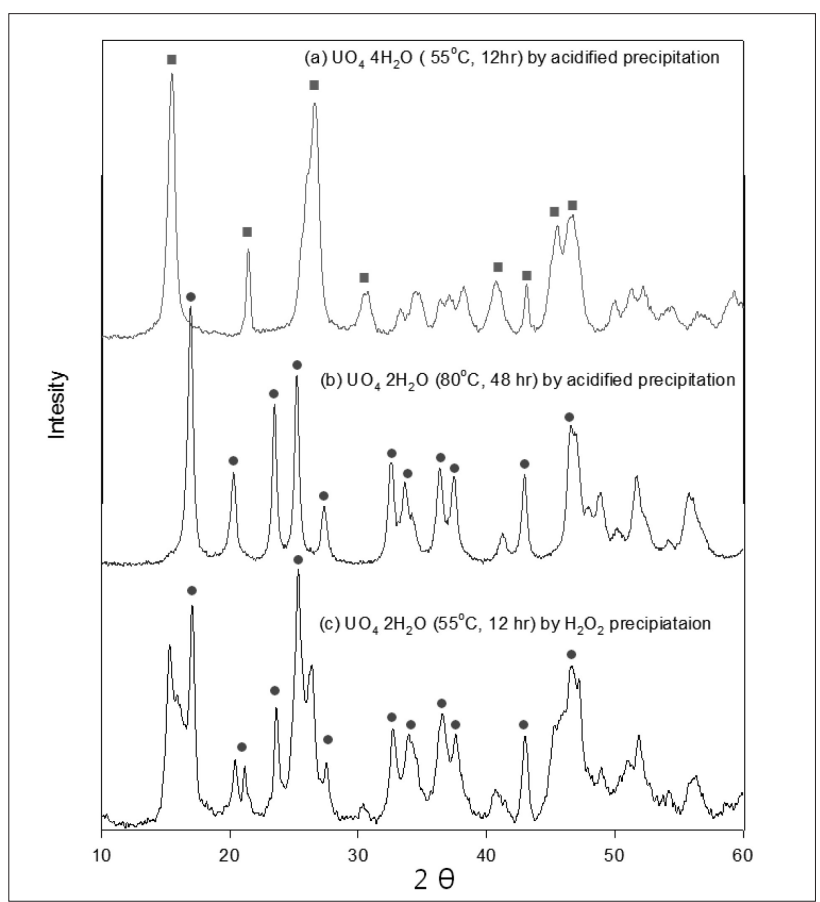

Fig. 12. XRD patterns of UO, precipitate obtained by an acidified precipitation and a $\mathrm{H}_{2} \mathrm{O}_{2}$ precipitation with change of drying condition in ULP of K-2. 
한 것으로 불순물의 peak가 다소 공존하는 $\mathrm{UO}_{4} \cdot 2 \mathrm{H}_{2} \mathrm{O}$ 로 나타났다. 이로부터 ULP에 함유되어 있는 U은 용해 및 침전 방법에 관계없이 $\mathrm{UO}_{4}$ 로의 제거(/회수)가 가능함을 알 수 있 다.

이상의 결과로부터 ULP로부터 U을 제거(/회수) 하기 위 해서는 용해 관점에서 질산 용해가 유리하나 (약 98\%) 이 경 우 다량의 공존 불순물이 U과 함께 용해되고, 과산화수소 침전에서도 상당량의 불순물이 $\mathrm{U}$ 과 함께 공침전 된다. 그러 나 탄산염 용해에 의한 산성화 침전에서는 U의 용해가 $90 \%$ 이하로 방사성 고체페기물의 부피감용 측면에서는 다소 비 효과적이지만 불순물과의 공용해 및 공침전 등을 억제할 수 있어 순수한 최종 $\mathrm{U}$ 을 회수하는 측면에서는 보다 효과적이 다.

\section{IV. 결 론}

$\mathrm{U}$-함유 석회침전물로부터 U을 제거(/회수) 하기위하여 탄산염 산화용해에 의한 산성화 침전과 질산용해에 의한 과 산화수소 침전을 각각 고찰하였다. 석회침전물의 용해 측면 에서는 질산용해가 유리하나, 최종 $\mathrm{U}$ 을 회수하는 측면에서 는 불순물과의 공용해/공침전 등을 고려하여 볼 때 탄산염 용해에 의한 산성화 침전이 보다 효과적이다. 탄산염 용액 에 의한 산화용해는 상온에서 $\mathrm{Na}_{2} \mathrm{CO}_{3}$ 의 농도는 $0.5 \mathrm{M}$ 이상, 산화제인 $\mathrm{H}_{2} \mathrm{O}_{2}$ 의 농도는 $1.0 \mathrm{M}$ 정도, 용해시간은 2 시간, 용 액 내 $\mathrm{pH}$ 은 10 11 정도가, 그리고 산성화 침전에서는 용액 내 $\mathrm{pH}$ 는 3 4, 침전시간은 1 시간 정도, 상온에서 각각 수행 하는 것이 U-함유 석회침전물로부터 공존 불순물의 공용해 및 공침전을 방지하면서 U만을 선택적으로 제거(/회수)할 수 있다.

\section{감사의 글}

본 연구는 교육과학기술부의 원자력 연구개발 중장기 계획 사업의 일환으로 수행된 연구 결과입니다.

\section{References}

[1] "Regulation for the receiving of low- and intermediate radioactive waste", Korea Radioactive Waste Management Corporation, (2009).

[2] "Regulation on the basis to estimate the cost of radioactive waste disposal and spent fuel management", Ministry of Knowledge Economy, Prescription No. 2011-197, (2011).

[3] International Atomic Energy Agency report, "Minimization of waste from uranium purification, enrichment and fuel fabrication", IAEA-TECDOC1115, (1999).

[4] B. L. Perkins, "Evaluation of environmental control technologies for commercial uranium nuclear fuel fabrication facilities", Los Alamos National Laboratory Report, LA-9398-MS (1983).

[5] D. W. Shoesmith, "Used fuel and uranium dioxide dissolution studies-review", NWMO TR-2007-03, Nuclear Waste Management Organization, (2008)

[6] K. W. Kim, D. Y. Chung, H. B. Yang, J. K. Lim, E. H. Lee, K. C Song, and K. Song, "A conceptual process study for recovery of uranium alone from spent nuclear fuel by using high-alkaline carbonate media", Nud. Tech. 166, pp. 170-179 (2009).

[7] S. M. Pepper, L. F. Brodnax, S. E. Field, R. A. Zehnder, S. N. Valdez, and W. H. Runde, "Kinetic study of the oxidation dissolution of $\mathrm{UO}_{2}$ in aqueous carbonate media", Ind. Eng. Chem. Res., 43, pp. 8188-8193 (2004).

[8] C. Soderquist, and B. Hanson, "Dissolution of spent nuclear fuel in carbonate peroxide solution", J. Nucl. Mat., 396, pp. 159-162 (2010).

[9] K. W. Kim, J. T. Hyun, E. H. Lee, G. I, Park, K. W. Lee, M. Y. Yoo, K. C Song, and J. K. Moon, "Recovery of uranium from (U,Gd)O $\mathrm{O}_{2}$ nuclear fuel scrap using dissolution and precipitation in carbonate media", J. Nucl. Mat., 418, pp. 93-97 (2011).

[10] N. Asanuma, M. Harada, Y. Ikeda and H. Tomiyasu, "New approach to nuclear fuel reprocessing in non-acidic aqueous solutions", J. Nucl. Sci. Tech., 38(10), pp. 866-871 (2001).

[11] C.F.V. Mason, W.R. J.R. Turney, B.M. Thomson, N. Lu, P.A. Longman, and C.J. Chisholm-Brause, "Cabonate leaching of uranium in contaminated soils", Enviro. Sci. Tech., 31(10), pp. 2707-2711 (1997).

[12] E. H. Lee, J. G. Lim, D. Y. Chung, H. B. Yang 


\section{Removal of Uranium from U-bearing Lime-Precipitate using ...}

and K. W. Kim, "Evaluation of $\mathrm{Na}_{2} \mathrm{CO}_{3}-\mathrm{H}_{2} \mathrm{O}_{2}$

(2005). carbonate solution Stability", J. Korean Radioactive Waste Soc., 9 (3), pp. 131-139 (2011).

[13] E. H. Lee, J. G. Lim, D. Y. Chung, H. B. Yang and K. W. Kim, "The characteristics of an oxidative dissolution of simulated fission product oxides in $\left(\mathrm{NH}_{4}\right)_{2} \mathrm{CO}_{3}$ solution containing $\mathrm{H}_{2} \mathrm{O}_{2}{ }^{\prime \prime}$, J. Korean Radioactive Waste Soc., 7(2), pp. 93-100 (2009)

[14] D. Y. Chung, H. S. Seo, J. W. Lee, H. B. Yang, E. H. Lee and K. W. Kim, "Oxidative leaching of uranium from SIMFUEL using $\mathrm{Na}_{2} \mathrm{CO}_{3}-\mathrm{H}_{2} \mathrm{O}_{2}$ solution", J. Radioanal. Nucl. Chem.. 284, pp 123129 (2010).

[15] J. A. Dean, "Lange's Handbook of Chemistry", 12th Edition, McGraw-Hill Book Company. (1979).

[16] E. Ekeroth and M. Jonsson, "Oxidation of $\mathrm{UO}_{2}$ by radiolytic oxidants", J Nucl. Mat., 322, pp. 242-248 (2003).

[17] E. H. Lee, J. K. Lim, D. Y. Chung, H. B. Yang, J. H. Yoo and K. W. Kim, "The oxidative-dissolution behaviors of fission products in a $\mathrm{Na}_{2} \mathrm{CO}_{3}-\mathrm{H}_{2} \mathrm{O}_{2}$ solution", J. Radioanal. Nucl. Chem., 281, pp. 339346 (2009).

[18] K. W. Kim, Y. H. Kim, S. Y. Lee, J. W. Lee, K. S. Joe, E. H. Lee, J. S. Kim, K. Song, and K. C. Song, "Precipitation Characteristics of Uranyl Ions at Different pHs Depending on the Presence of Carbonate Ions and Hydrogen Peroxide", Envion. Sci. Technol., 43, pp. 2355-2361 (2009)

[19] K. W. Kim, Y. H. Kim, E. H. Lee, K. Song, and K. C. Song, "Study on electrolytic recoveries of carbonate salt and uranium from a uranyl peroxy carbonato complex solution generated from a carbonate-leaching process", Ind. Eng. Chem. Res., 49, pp. 2085-2092 (2009).

[20] R. C. Merritt, "The extractive metallurgy of uranium", Colorado school of Mines Research Institute, United States Atomic Energy Commission, (1971).

[21] R. Djogic, V. Cuculic, M. Branica, "Precipitation of uranium (IV) peroxide $\left(\mathrm{UO}_{4}\right)$ in sodium perchlorate solution", Croatica Chimica Acta, 78(4), pp. 575-580 